\title{
Protective Effect of Cordia Myxa Extract on Changes in Body Weight, Serum Proteins, Albumin and Liver Histology of Adult Male Rats Induced by Cadmium Chloride Toxicity
}

\author{
Mojtaba Shahriari1(D), Davood Moghadamnia*2 \\ ${ }^{1}$ Department of Biology, Kazerun Branch, Islamic Azad University. Kazerun, Iran. \\ ${ }^{*} \mathrm{PhD}$ of Animal Physiology Young Researchers and Elite Club, Shiraz Branch, Islamic Azad University. Shiraz, Iran.
}

\begin{tabular}{|c|c|}
\hline Article Info & B $S$ \\
\hline & \multirow{4}{*}{$\begin{array}{l}\text { Background: } \\
\text { The present study investigated the protective effect of } \mathrm{C} \text {. myxa extract on the } \\
\text { liver biochemical and histologic changes induced by cadmium chloride }(\mathrm{CdCl} 2) \text { in } \\
\text { adult male rats. } \\
\text { Methods: } \\
\text { We used } 48 \text { adults male Wistar rats, divided into } 6 \text { groups of } 8 \text {. Control group } \\
\text { received water and normal food. Sham group } 1 \text { received } 2 \mathrm{mg} / \mathrm{kg} \text { of } \mathrm{CdCl} 2 \text { for } 35 \\
\text { days intraperitoneally. In Addition, Sham Group } 2 \text { received } 125 \mathrm{mg} / \mathrm{kg} \text { extract of } \\
\text { C. myxa fruit for } 35 \text { days by gavage method. The experimental groups } 1,2 \text { and } 3 \\
\text { received } 125,250 \text { and } 500 \mathrm{mg} / \mathrm{kg} \text { of } \mathrm{C} \text {. myxa extract for } 21 \text { days through gavage, } \\
\text { followed by } 2 \mathrm{mg} / \mathrm{kg} \text { of } \mathrm{CdCl} 2 \text { given intraperitoneally for } 14 \text { days. After the } \\
\text { experimentation period, blood samples were taken and the serum total protein } \\
\text { and albumin concentrations measured. Also, liver tissue sections were prepared, } \\
\text { stained and examined by light microscopy to evaluate the histologic changes. }\end{array}$} \\
\hline Articl & \\
\hline & \\
\hline $\begin{array}{l}\text { * Corresponding author: } \\
\text { Davood Moghadamnia } \\
\text { PhD of Animal Physiology Young } \\
\text { Researchers and Elite Club, Shira } \\
\text { Branch, Islamic Azad University. } \\
\text { Shiraz, Iran } \\
\text { E-mail: } \\
\text { davood.moghadamnia@gmail.co }\end{array}$ & \\
\hline
\end{tabular}

\section{Results:}

The mean body weight, serum total protein, albumin in sham group 1 showed a significant decrease in comparison with those in the controls and Sham Group 2. The mean body weight and serum total protein in Experimental Groups 2 and 3 showed a significant increase compared to those in Sham Group 1. The mean serum albumin in Experimental Group 3 showed a significant increase compared to that in Sham Group $1(\mathrm{P}<0.05)$.

\section{Conclusion:}

The extract of C. myxa fruit demonstrated protective effects on changes in body weight, serum biochemical factors and liver histology induced by the adverse effect of $\mathrm{CdCl} 2$ in adult male rats.

Keywords:

Cadmium Chloride; Extract of Cordia Myxa; Liver Histology; Male Adult Rats.

How to cite this paper

Shahriari M, Moghadamnia D. Protective Effect of Cordia Myxa Extract on Changes in Body Weight, Serum Proteins, Albumin and Liver Histology of Adult Male Rats Induced by Cadmium Chloride Toxicity. Iran J toxicol. 2019; (2): 43-49

\section{INTRODUCTION}

Cadmium (Cd) is a chemical element in the periodic table with the atomic number 48 (1). This 2-valent, relatively scarce metal is malleable, flexible, and whitewater colored metal, which can easily be cut with a knife $(\underline{2,3})$. Cd-contaning compounds have caused tumors in several species of laboratory animals and organ tissues (4). Exposure to various Cd compounds can cause lung cancer in rats, the prevalence of which increases with the level of exposure. In mice exposed to $\mathrm{Cd}$ compounds, pulmonary tumors have been reported (ㅁ) . Also, the oral application of $\mathrm{CdCl}_{2}$ in rats has increased the prevalence of leukemia and stimulated elliptical tumors ( $\underline{6})$.

The subcutaneous injection of $\mathrm{Cd}$ compounds leads to tumor formation in various animal tissues, including prostate tumor in rats; lymphoma, liver and lung tumors in mice; andadrenal tumors in hamster and mice (7). The subcutaneous administration of $\mathrm{CdCl}_{2}$ in rats has led to the formation of pituitary gland tumors, and exposure to oral $\mathrm{CdCl}_{2}$ has increased the prevalence of renal tumors in dose-dependent manner (7). In vitro studies in rat and human hepatocytes have shown that planned cell death plays an important role in Cd-induced liver toxicity (ㅁ). A study (ㅁ) by Pham 
and colleagues proposed non-adjacent pathways for mitochondrial mediated caspase in $\mathrm{Cd}$-induced cell death in early hepatocyte cultures in rats, and pretreatment with a caspase inhibitor did not prevent the preprogrammed cell death or apoptosis (ㅁ)

Liver is the largest gland in the body and is covered with a thick fibrous layer, called Glisson's capsule, which becomes thicker between in the four lobes of the liver. This capsule surrounds the hepatic vein, artery and the common bile duct $(\underline{10})$. The liver portal space contains the portal vein, artery, and the bile duct. In addition, lymphatic vessels and nerves are also present in this area $(\underline{10})$.

Cordia myxa is a flowering plant that grows primarily in Asia, with spherical fruits and broad, crusty leaves (11). The fruits contain such compounds as flavonoids, sterols, phenolic acids, saponins, terpenoves, alkaloids, coumarins and tannins (12). The C. myxa fruits are used as expectorant, laxative and diuretic agents, and to treat urinary tract infections ( $\underline{13})$. In addition, it has been reported that the extract of $\mathrm{C}$. myxa leaves has anti-diarrhea, anti-inflammatory and analgesic properties in rats $(\underline{14})$. The anti-inflammatory effect of of C. myxa fruits has been shown in the treatment of human colitis (15). Considering the antioxidant properties of the C. myxa fruits, this study investigated the protective effect of the extract on the biochemical and tissue alterations in the male rat liver in response to exposure to $\mathrm{CdCl}_{2}$.

\section{MATERIALS AND METHODS}

Animals: We used 48 adult male Wistar rats, weighing 200-225 grams and 2.5-3 months old. Animals were randomly assigned to 6 groups of 8 animals and kept in standard cages treated under identical conditions at $23^{\circ} \mathrm{C} \pm 2$ and with 12-hour light and 12-hour darkness. They were provided with ample water and food, and all ethical considerations regarding experimental animals were observed about them.

\section{Preparation of Hydro-Alcoholic Extract of C.} Myxa Fruit: Cordia myxa fruits were collected at gardens around Kazerun city in Fars province, under appropriate conditions and away from the sun. The fruits were separated from branches and crushed in a mixing machine. Then $500 \mathrm{~g}$ of the blended fruits was placed in a percolation device.A 70\% hydroalcoholic solution was added such that the solution surface was several centimeters higher than the surface of the crushed fruit, and kept at room temperature. After 72 hours, the the percolator valve was opened and the extract droplets were collected and added from the top with a droplet separating hopper of the hydroalcohol solution until the extract was no longer colored from the plant. The extract was then concentrated in a rotary or binary apparatus at $50-40^{\circ} \mathrm{C}$, and lyophilized in a desiccators for 24 hours $(\underline{16})$.

Animal Grouping: Animals were randomly divided into 6 groups of 8 . The control group received normal water and food and no treatment given. All treatments in both sham and experimental groups were given once daily for the duration specified for each group. The sham group 1 received $2 \mathrm{mg} / \mathrm{kg}$ of $\mathrm{CdCl}_{2}$ for 35 days intraperitoneally. The sham group 2 received 125 $\mathrm{mg} / \mathrm{kg}$ of the extract of C. myxa for 35 days by gavage method. The experimental group 1 received $125 \mathrm{mg} / \mathrm{kg}$ of the extract by gavage method for 21 days and then given $2 \mathrm{mg} / \mathrm{kg}$ of $\mathrm{CdCl}_{2}$ solution daily by intraperitoneal injection for 14 days. The experimental group 2 received $250 \mathrm{mg} / \mathrm{kg}$ extract by gavage method for 21 days and then given $2 \mathrm{mg} / \mathrm{kg} \mathrm{CdCl}_{2}$ solution by intraperitoneal injection for 14 days. The experimental group 2 received $500 \mathrm{mg} / \mathrm{kg}$ of the extract by gavage method for 21 days and then given $2 \mathrm{mg} / \mathrm{kg} \mathrm{CdCl}_{2}$ solution by intraperitoneal injection for 14 days. The doses and administration methods had been tested successfully by previous studies $(\underline{17,18})$.

At the completion of the study, all animals were anesthetized with ether and blood samples were collected from the hearts' left ventricle. Blood samples were carefully labeled and centrifuged at at $5000 \mathrm{rpm}$ for 15 minutes to separate the serum. Blood samples' biochemical parameters, such as albumin, bilirubin and total protein were determined, using a calibrated autoanalyzer (Technicon RA-1000; USA).

Histological Experiments: After the autopsy, the animals' liver was removed and were fixed in neutral $10 \%$ formalin buffer. The tissue dehydration was carried out, using alcohol at different concentrations. The clarification step was carried out by placing the tissues in two xylan containers. In the infiltration stage, the tissues were soaked in melted paraffin $\left(65^{\circ} \mathrm{C}\right)$ for an hour. In the molding stage, leukhardt parts were used. Tissue sections were made at 4.5 microns and stained with hematoxylin and eosin ( $\mathrm{H} \& \mathrm{E}$ ). All histological examinations were conducted under the supervision of a pathologist (19).

Statistic Analysis: The data were analyzed by ANOVA and Tukey tests, using SPSS software version 18. Tthe statistical level of significance was set at $\mathrm{P}<0.05$ among the groups.

\section{RESULTS}

Body Weight: The mean body weight, total protein and albumin among the groups before and after the extract administration are shown in Table 1 . The mean body weights before administrating the extract were not significantly different in any of the groups compared to that in the controls (Table 1). However, this parameter significantly decreased in all groups compared to that in the controls after the extract administration. Overall, the mean total serum protein and albumin decreased significantly in all groups except for the controls after the administration of the extract. However, the mean body weight in the experimental group 3 was significantly higher than those in the experimental groups 1 and 2. The mean of body weight in experimental group 2 increased insignificantly compared to that in experimental group $1(\mathrm{P}<0.05)$. 
Serum Proteins: Mean total serum total protein concentration in experimental group 3 showed a significant increase compared to that in experimental groups 1 and 2 . The serum total protein concentration in both sham and experimental groups 1 showed a significant decrease compared to that in sham group2 and the controls. Likewise, the total protein concentration in experimental groups 2 and 3 showed a significant decrease compared to those in sham group2 and the controls. Also, the protein concentration in experimental group 1 decreased insignificantly compared to that in experimental group 2. Also, there was no significant difference between the total protein concentration in sham group 2 and the controls $(\mathrm{P}<0.05)$.
Serum Albumin: The serum albumin in the experimental group 3 showed a significant increase compared to the experimental groups 1 and 2. Also, serum albumin in experimental group 1 increased significantly compared to that in experimental group 2 $(\mathrm{P}<0.05)$. The serum albumin in the experimental and sham groups 1 showed a significant decrease compared to those in sham group 2 and the controls. Serum albumin concentration in experimental groups 2 and 3 showed a significant decrease compared to those in sham group 2 and the controls. The mean serum albumin in the control group and sham group 2 was not significantly different from each other.

Table 1. Changes in the mean body weight before and after the treatments in each group.

\begin{tabular}{|c|c|c|c|c|}
\hline Group & $\begin{array}{c}\text { Treatment } \\
\text { (35 days) }\end{array}$ & $\begin{array}{c}\text { Before Treatment } \\
(\mathrm{g})\end{array}$ & $\begin{array}{c}\text { After Treatment } \\
(\mathrm{g})\end{array}$ & $\begin{array}{c}\text { Change } \\
(\%)\end{array}$ \\
\hline Control Group & Normal food \& water only & $211.66 \pm 8.30$ & $262.66 \pm 17.58$ & +24.1 \\
\hline Sham Group 1 & $2 \mathrm{mg} / \mathrm{kg} \mathrm{CdCl} 2$ & $210 \pm 10.35$ & $146.50 \pm 24.85^{\text {a }}$ & $-31.2^{\mathrm{a}}$ \\
\hline Sham Group 2 & $\begin{array}{l}125 \mathrm{mg} / \mathrm{kg} \text { extract, and } \\
2 \mathrm{mg} / \mathrm{kg} \mathrm{CdCl}{ }_{2} \text { together }\end{array}$ & $207.14 \pm 11.60$ & $244.14 \pm 32.66^{b}$ & $+17.9^{b}$ \\
\hline Experimental Group 1 & $\begin{array}{l}125 \mathrm{mg} / \mathrm{kg} \text { extract (21d) } \\
\rightarrow 2 \mathrm{mg} / \mathrm{kg} \mathrm{CdCl} \\
(14 \mathrm{~d})\end{array}$ & $207.85 \pm 6.46$ & $200.85 \pm 27.12^{\mathrm{b}}$ & $-3.4^{b}$ \\
\hline Experimental Group 2 & $\begin{array}{l}250 \mathrm{mg} / \mathrm{kg} \text { extract }(21 \mathrm{~d}) \\
\rightarrow 2 \mathrm{mg} / \mathrm{kg} \mathrm{CdCl}(14 \mathrm{~d})\end{array}$ & $209.27 \pm 9.42$ & $204.85 \pm 16.43^{b}$ & $-2.1^{b}$ \\
\hline Experimental Group 3 & $\begin{array}{l}500 \mathrm{mg} / \mathrm{kg} \text { extract }(21 \mathrm{~d}) \\
\rightarrow 2 \mathrm{mg} / \mathrm{kg} \mathrm{CdCl}_{2}(14 \mathrm{~d})\end{array}$ & $209.27 \pm 11.15$ & $215.14 \pm 20.60^{b}$ & $+2.8^{\mathrm{b}}$ \\
\hline
\end{tabular}

$\mathrm{d}=$ Days of specific treatment; $\rightarrow=$ Extract treatment was followed by $\mathrm{CdCl}_{2}$ treatment for 14 days.

$\mathrm{a}=$ Denotes a significant difference compared to the control group $(\mathrm{P}<0.05)$.

$\mathrm{b}=$ Denotes a significant difference compared to Sham Group $1(\mathrm{P}<0.05)$.

Histologic Results: The microscopic examination of the liver sections was carried out for all groups (Fig. 1). In the control group, the liver tissue appeared completely normal and without observable cellular damages. Specifically, the tissue architecture represented the normal radial cells with the characteristic nuclei- and central veins (Fig. 1). In sham group 1, cellular damage, such as cytoplasmic inflammation, nucleus swelling, vacuole and necrotis areas (Figure. 2). In sham group 2, no abnormal changes were observed and the tissue sections looked healthy, similar to those noted in the controls (Figure. 3).

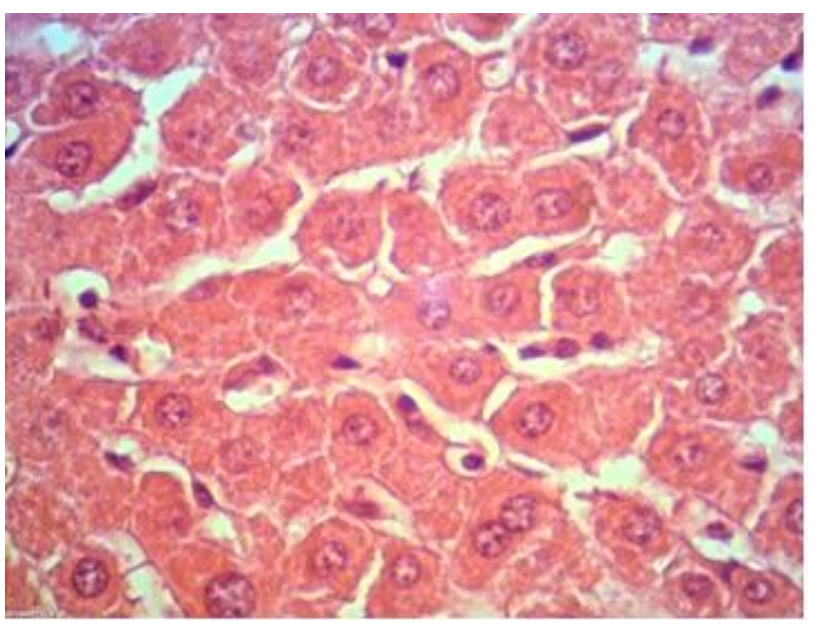

Figure 1. Control Group - Micrograph of normal rat liver tissue from the control group (normal food and water x 35d). (H \& E stain; mag. $\times 400$ ) H \& E stain; mag. $\times 400$ ).

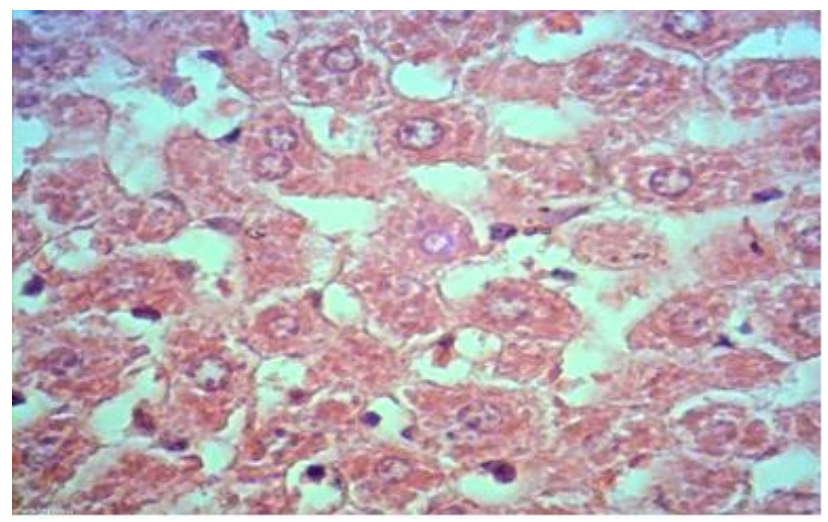

Figure 2. Sham Group 1 - Micrograph of rat liver tissue $(2 \mathrm{mg} / \mathrm{kg}$ $\mathrm{CdCl}_{2} \times 35 \mathrm{~d}$ ). (H \& E stain; mag. $\left.\times 400\right)$.

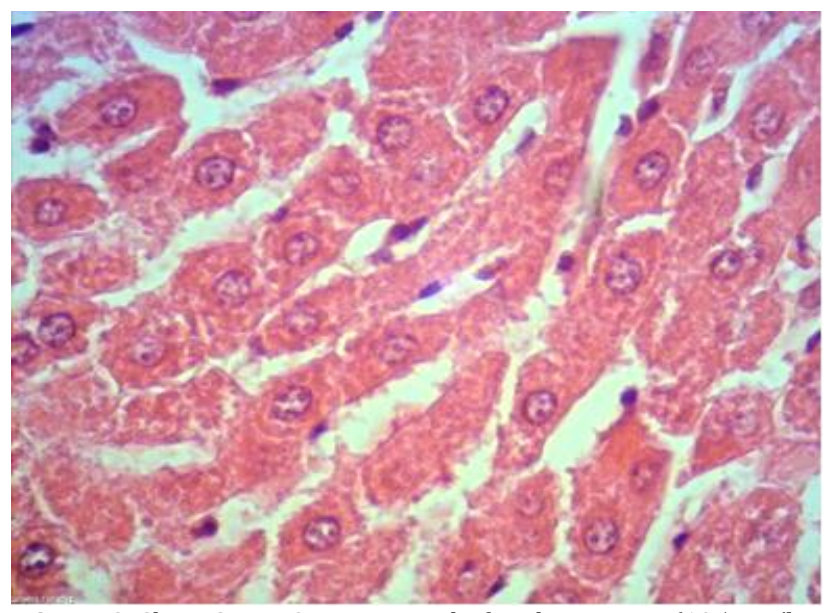

Figure 3. Sham Group 2 - Micrographof rat liver tissue $(125 \mathrm{mg} / \mathrm{kg}$ extract $+2 \mathrm{mg} / \mathrm{kg} \mathrm{CdCl} 2 \times 35 \mathrm{~d}$ ). (H \& E stain; mag. $\times 400$ ). 
In experimental group 1, signs of cellular damages were observed similar to those in sham group 2, but less severe than those in sham group 1 (Figure. 4). In the experimental group 2, signs of mild tissue necroses were observed compared to those noted in sham group 2 (Figure. 5). In experimental group 3, no abnormal tissue and cellular damages were observed, and sections appeard almost similar to the controls (Figure. 6). Of note, the rate of tissue damages declined proportionally with an increase in the extract dosage.

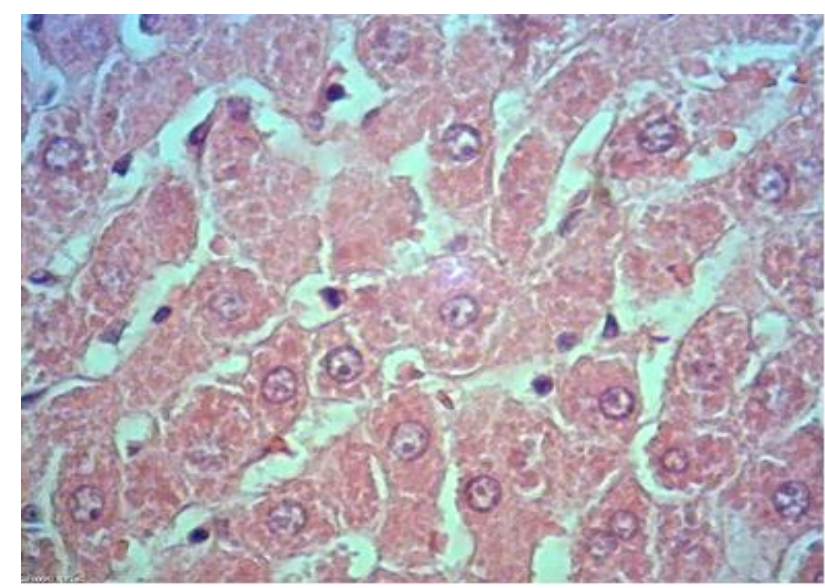

Figure 4. Experimental Group 1 - Micrograph of rat liver tissue (125 $\mathrm{mg} / \mathrm{kg}$ extract $\mathrm{x} 21 \mathrm{~d} \rightarrow 2 \mathrm{mg} / \mathrm{kg} \mathrm{CdCl} 2$ x $14 \mathrm{~d}$ ). ( $\mathrm{H} \& \mathrm{E}$ stain; mag. $\times 400$ ).

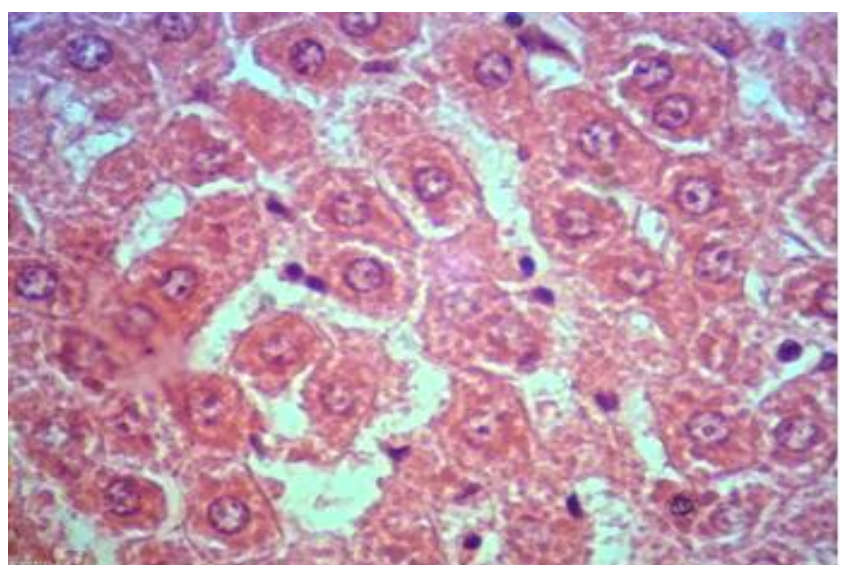

Figure 5. Experimental Group 2 - Micrograph of rat liver tissue (250 $\mathrm{mg} / \mathrm{kg}$ extract $\mathrm{x} 21 \mathrm{~d} \rightarrow 2 \mathrm{mg} / \mathrm{kg} \mathrm{CdCl} \mathrm{Cd}_{2}$ 14d). (H \& E stain; mag. $\times 400$ ).

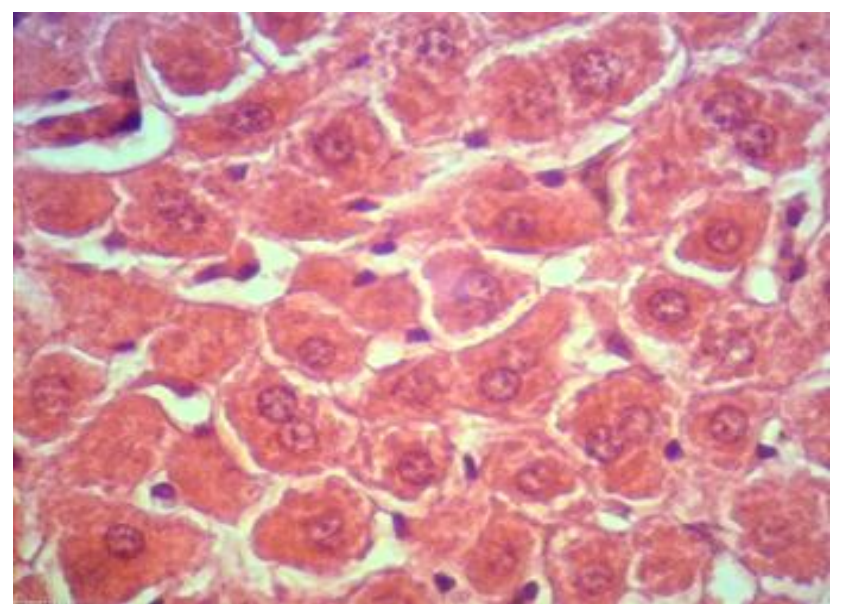

Figure 6. Experimental Group 3 - Micrograph of rat liver tissue (500 $\mathrm{mg} / \mathrm{kg}$ extract $\mathrm{x} 21 \mathrm{~d} \rightarrow 2 \mathrm{mg} / \mathrm{kg} \mathrm{CdCl} 2 \times 14 \mathrm{~d}$ ). (H \& E stain; mag. $\times 400$ ).

\section{DISCUSSION}

Changes in Body Weight: The results indicated that the rats in Sham Group 1 that only received $\mathrm{CdCl}_{2}$ treatments had a major weight loss $(31.2 \%)$ while those in the control group gained a significant body weight $(24.1 \%)$ during the same study period (35d). This finding alone reflects the destructive effect of $\mathrm{CdCl}_{2}$ in the rats when it is used alone. Conversly, the rats in Sham Group 2 that received the extract and $\mathrm{CdCl}_{2}$ treatments concurrently had a significant weight gain $(17.9 \%)$ during the same study period. The latter results suggest a protective effect for the C. myxa extract in these animals. In terms of the mechanism of action, this study does not have the data to prove a specific destructive action for $\mathrm{CdCl}_{2}$; however, it would be interesting to know whether the extract blocked the toxic effect of $\mathrm{CdCl}_{2}$ by binding the tissue sites or it inhibited the molecular action of $\mathrm{CdCl}_{2}$ by directly binding the metal, thereby preventing tissue damages that accounted for the weight loss in Sham Group 1.

With respect to the Experimental Groups 1-3, both the weight loss $(-3.4 \%$ \& $-2.1 \%)$ and gain $(+2.8 \%)$ was much lower than those noted in Sham Groups 1 ($31.2 \%)$ and $2(+17.9 \%)$, respectively. Despite the multiple variables that might be responsible for the significantly less weight losses, we can argue that these changes might be associated with at least three conceivable factors, such as, a) shorter $\mathrm{CdCl}_{2}$ exposure (14d Vs 35d) of the rats; $\boldsymbol{b}$ ) prior presence of C. myxa extract in rats, which might have provided a protective effect as was suggested for Sham Group 2 earlier; and c) the dose-dependent protective effect of the extract, which might have promoted a more favorable growth rate in the rats, depending on the dosage.

The mechanism by which the rats did not suffer a signifant weigth loss in Sham Group 2 and the Experimental groups, compared to Sham Group 1, might be linked to the protective effect of rutin, a $C$. myxa extract constituent, against the toxicity of $\mathrm{CdCl}_{2}$. Several studies (20-23) have shown that rutin has protective effects on lipid dysfunction caused by toxic elements through its antioxidant property and the expression of antioxidant genes. Further, another component of C. туха extract, phytosterol, has been suggested by several studies (24-27) to involve intestinal disturbances in fatty acid reuptake and modulation of liver lipogenesis. This mechanism might have a preventive role against body weight losses in rats observed in this study. The elucidation of other important mechanisms by which C. myxa extract protects against cadmium toxicity awaits further research.

Changes in Serum Proteins: The fact that there was a $33 \%$ decline in serum proteins in Sham Group 1 compared to the controls reflects the toxic effect of $\mathrm{CdCl}_{2}$ on the protein synthesis system, which is primarily the liver. The protective effect of $C$. туха extract is clearly reflected by a $39.3 \%$ rise in the serum proteins observed in Sham Group 2, compared to that in Sham Group 1. In Experimental Groups 1 and 2, the 
presumable inhibition of protein synthesis by $\mathrm{CdCl}_{2}$ reflects a decreasing trend as the concentration of $\mathrm{C}$. myxa extract goes from 125 to $250 \mathrm{mg} / \mathrm{kg}$ compared to that in the controls $(-23.7 \%$ vs $-17 \%)$. Compared to the protein synthesis level in Sham Group 1, there was a $23.9 \%$ and $47.2 \%$ greater increase in protein synthesis in Experimental Groups 2 and 3, respectively, as the concentration of the extract increased from 250 to 500 $\mathrm{mg} / \mathrm{kg}$. The pattern of serum protein synthesis both for Sham and Experimental groups further supports the protective effects of the $C$. myxa extract at varying rates. The data in Table 2 suggest that a greater level of serum protein synthesis (39.3\%; Sham Group 2) was generated when the extract was present concurrently with $\mathrm{CdCl}_{2}$ in rats, thereby causing a greater inhibition on the toxic effect of cadmium. Further support for the protective effect of $C$. myxa extract comes from the greater serum protein synthesis levels of $23.9 \%$ and $47.2 \%$ for Experimental Groups 2 and 3, respectively, as the extract concentration increased from 250 to 500 $\mathrm{mg} / \mathrm{kg}$ (Table 2). The data in Table 2 further suggest that the protective effect of the extract on serum protein synthesis is better maintained when it is present with cadmium, even at one forth of the concentration (125 vs $500 \mathrm{mg} / \mathrm{kg}$ ).

Studies have shown that the hepatoprotective effects of rutin and caffeic acid in certain liver diseases involve blocking the oxidative damages and inflammation caused by toxic compounds in animal models (28-33). Also, the protective effect of caffeic acid on the liver may involve the inhibition of tumor growth factor $B$ which induces cellular autophagy and inflammatory response ( $\underline{34-35})$. In this study, it was highly likely that rutin and caffeic acid supported the liver protein synthesis capacity where $C$. myxa extract was present either throughout the $\mathrm{CdCl}_{2}$ treatment (Sham Group 2) or was given prior to that intervention (Experiemental Groups). The latter suggests the lasting protective effect of the C. myxa extract.

Table 2. Changes in the mean serum protein and albumin levels after all treatments.

\begin{tabular}{|c|c|c|c|c|c|}
\hline Group & $\begin{array}{c}\text { Treatment } \\
\text { (35 days) }\end{array}$ & $\begin{array}{c}\text { Serum Proteins } \\
(\mathrm{mg} / \mathrm{dl})\end{array}$ & $\begin{array}{c}\text { Change } \\
(\%)\end{array}$ & $\begin{array}{c}\text { Serum Albumin } \\
(\mathrm{mg} / \mathrm{dl})\end{array}$ & $\begin{array}{c}\text { Change } \\
(\%)\end{array}$ \\
\hline Control Group & Normal food \& water only & $5.31 \pm 17.58$ & 0 & $2.73 \pm 0.28$ & 0 \\
\hline Sham Group 1 & $2 \mathrm{mg} / \mathrm{kg} \mathrm{CdCl} 2$ & $3.56 \pm 0.21^{a}$ & $-33^{a}$ & $1.80 \pm 0.10^{a}$ & $-34.1^{a}$ \\
\hline Sham Group 2 & $\begin{array}{l}125 \mathrm{mg} / \mathrm{kg} \text { extract, and } \\
2 \mathrm{mg} / \mathrm{kg} \mathrm{CdCl}{ }_{2} \text { together }\end{array}$ & $4.96 \pm 0.48^{b}$ & $+39.3^{\mathrm{b}}$ & $2.71 \pm 0.20^{b}$ & $+50.5^{\mathrm{b}}$ \\
\hline $\begin{array}{l}\text { Experimental } \\
\text { Group } 1\end{array}$ & $\begin{array}{l}125 \mathrm{mg} / \mathrm{kg} \text { extract }(21 \mathrm{~d}) \\
\rightarrow 2 \mathrm{mg} / \mathrm{kg} \mathrm{CdCl} \\
(14 \mathrm{~d})\end{array}$ & $4.05 \pm 0.23^{\mathrm{a}}$ & $-23.7^{a}$ & $2.02 \pm 0.23^{a}$ & $-26^{a}$ \\
\hline $\begin{array}{l}\text { Experimental } \\
\text { Group } 2\end{array}$ & $\begin{array}{l}250 \mathrm{mg} / \mathrm{kg} \text { extract (21d) } \\
\rightarrow 2 \mathrm{mg} / \mathrm{kg} \mathrm{CdCl} \\
(14 \mathrm{~d})\end{array}$ & $4.41 \pm 0.29 \mathrm{a}, \mathrm{b}$ & $\begin{aligned} & -17^{a} \\
+ & 23.9^{b}\end{aligned}$ & $1.97 \pm 0.41^{\mathrm{a}}$ & $-17.8^{a}$ \\
\hline $\begin{array}{l}\text { Experimental } \\
\text { Group } 3\end{array}$ & $\begin{array}{l}500 \mathrm{mg} / \mathrm{kg} \text { extract }(21 \mathrm{~d}) \\
\rightarrow 2 \mathrm{mg} / \mathrm{kg} \mathrm{CdCl}_{2}(14 \mathrm{~d})\end{array}$ & $5.24 \pm 0.34^{b}$ & $+47.2^{\mathrm{b}}$ & $2.45 \pm 0.26^{b}$ & $+36.1^{\mathrm{b}}$ \\
\hline
\end{tabular}

$\mathrm{d}=$ Days of specific treatment; $\rightarrow=$ Followed by a $\mathrm{CdCl}_{2}$ treatment for14 days.

$\mathrm{a}=$ Denotes a significant difference compared to the control group $(\mathrm{P}<0.05)$.

$\mathrm{b}=$ Denotes a significant difference compared to Sham Group $1(\mathrm{P}<0.05)$.

Changes in Serum Albumin: The results showed that the mean serum albumin concentration in Sham Group1, receiving $\mathrm{CdCl}_{2}$ alone for 35 days, was lower by $34.1 \%$ than that for the controls. Conversely, the serum albumin in Sham Group 2 increased by $50.5 \%$ compared with that for Sham Group 1. The findings strongly suggest that $\mathrm{CdCl}_{2}$ inhibited the albumin synthesis in Sham 1 Group; however, the presence of $\mathrm{C}$. myxa extract essentially reversed that effect completely in Sham Group 2, bringing the serum albumin level to that observed in the controls (2.71 vs $2.73 \mathrm{mg} / \mathrm{dl})$.

In Experimental Groups 1 and 2, the presumable inhibition of serum albumin synthesis by $\mathrm{CdCl}_{2}$ reflects a decreasing trend as the concentration of C. myxa extract doubled from 125 to $250 \mathrm{mg} / \mathrm{kg}$, compared to that in the controls ( $-26 \%$ vs $-17.8 \%)$. Surprisingly, raising the extract concentration to $500 \mathrm{mg} / \mathrm{kg}$ in Experimental Group 3 caused a significant increase $(+36.1 \%)$ in the serum albumin level, compared to that for Sham Group 1. Similarly to our findings for the serum protein level, the C. myxa extract provided a lasting protective effect for serum albumin synthesis in a dose dependent manner, even though it was administered prior to the start of $\mathrm{CdCl}_{2}$ treatments, thereby inhibiting the toxic effect to the liver.
In this study, rutin and caffeic acid might have protected not only the liver protein synthesis but also that of the albumin. This effect was evident whether $C$. myxa extract was present throughout the $\mathrm{CdCl}_{2}$ treatment (Sham Group 2) or it was introduced prior to $\mathrm{CdCl}_{2}$ intervention (Experiemental Groups). In this context, the lasting protective effect of the extract was evident.

Histological Changes: The cellular damage, such as cytoplasmic inflammation, nuclear swelling, vacuoles and necrotic cells, compared to the controls, reflect the toxic effect of $\mathrm{CdCl}_{2}$ (Figure. 2). However, the close to normal appearance of the tissue structures with slightly larger vacuoles in Sham Group 2 supports the protective effect of $C$. myxa extract on the rat liver tissue when used concurrently (Fig. 3). The histologic results in the Experimental groups clearly suggests the dose-dependent effect of $C$. myxa extract in protecting the hepatic cell structures from getting damage by the toxic effect of $\mathrm{CdCl}_{2}$. In Experimental Group 1 widespread cell damages were seen such as cytoplasmic and nuclear swelling, vacuoles and cell necrosis (Fig. 4) but less intense than those noted for Sham Group 1, suggestive of the mild protective effect of the extract when administered prior to $\mathrm{CdCl}_{2}$. The protective effect of the extract increased progressively 
in Experimental Groups 2 and 3, which suggest two important properties for it, i.e., dose-dependent and lasting effects. These were evident by the presence of mild cell necrosis in Experimental Groups 2 but no cell damage or necrosis observed in Experimental Group 3 and with the cells appearing almost like those in the control group.

The protective effect of C. myxa extract components, i.e., rutin, phytosterol and caffeic acid on the liver tissue may be explained by the above histologic findings in the rat liver tissue. It is highly conceivable that the antioxidant, anti-inflammatory and plasma membrane stabilizing effects of the above components of the extract have had a role in the preservation of the hepatic tissue structures in rats treated with $\mathrm{CdCl}_{2}(\underline{28-}$ 33).

\section{CONCLUSION}

The results of this study indicated that changes in body weight, serum total proteins, albumin and liver histology were influenced adversely by the administration of $\mathrm{CdCl}_{2}$ in male rats. However, the protective property of $C$. myxa extract significantly prevented the toxic effect of $\mathrm{CdCl}_{2}$ in these animals, when administered either concurrently or in advance of the cadmium exposure. Also, the protective effect of the extract was both lasting and dose-dependent against the oxidative and inflammatory effects induced by cadmium in the animals used in this study.

\section{ACKNOWLEDGEMENTS}

The authors sincerely appreciate the support of the Vice-Chancellor for Research at Kazerun Azad University. Funding was provided by Department of Biology, Kazerun Branch, Islamic Azad University, Kazerun, Iran.

\section{CONFLICT OF INTEREST}

There was no conflict of interests in conducting this research.

\section{REFERENCES}

1. Meija J, Coplen TB, Berglund M, Brand WA, De Bièvre P, Gröning M, et al. Atomic weights of the elements 2013 (IUPAC Technical Report). Pure and Applied Chemistry. 2016;88(3):265-291.

2. Kopp SJ, Glonek T, Perry HM, Erlanger M, Perry EF. Cardiovascular actions of cadmium at environmental exposure levels. Science. 1982;217(4562):837-839.

3. Yamano T, Shimizu M, Noda T. Comparative effects of repeated administration of cadmium on kidney, spleen, thymus, and bone marrow in 2-, 4-, and 8-month-old male Wistar rats. Toxicological sciences. 1998;46(2):393-402.

4. Huff J, Lunn RM, Waalkes MP, Tomatis L, Infante PF. Cadmium-induced cancers in animals and in humans. International journal of occupational and environmental health. 2007;13(2):202-212.

5. Sorahan T, Lancashire RJ. Lung cancer mortality in a cohort of workers employed at a cadmium recovery plant in the United States: an analysis with detailed job histories. Occupational and environmental medicine. 1997;54(3):194-201.

6. Waalkes MP, Anver M, Diwan BA. Carcinogenic effects of cadmium in the noble $(\mathrm{NBL} / \mathrm{Cr})$ rat: induction of pituitary, testicular, and injection site tumors and intraepithelial proliferative lesions of the dorsolateral prostate. Toxicological sciences: an official journal of the Society of Toxicology. 1999;52(2):154-161.

7. Waalkes MP, Anver MR, Diwan BA. Chronic toxic and carcinogenic effects of oral cadmium in the Noble (NBL/Cr) rat: induction of neoplastic and proliferative lesions of the adrenal, kidney, prostate, and testes. Journal of Toxicology and Environmental Health Part A. 1999;58(4):199-214.

8. Lasfer M, Vadrot N, Aoudjehane L, Conti F, Bringuier AF, Feldmann G, et al. Cadmium induces mitochondriadependent apoptosis of normal human hepatocytes. Cell biology and toxicology. 2008;24(1):55-62.

9. Pham TN, Marion M, Denizeau F, Jumarie C. Cadmiuminduced apoptosis in rat hepatocytes does not necessarily involve caspase-dependent pathways. Toxicology in vitro. 2006;20(8):1331-1342.

10. Busuttil RW, Klintmalm GB. Transplantation of the Liver E-Book. Elsevier Health Sciences; 2014 Dec 24.

11. Afzal M, Obuekwe C, Khan AR, Barakat H. Antioxidant activity of Cordia myxa L. and its hepatoprotective potential. Electron. J. Environ. Agric. Food Chem. 2007;6:2236-2242.

12. Inas ZA, Hala AK, Gehan HH. Gastroprotective effect of Cordia myxa L. fruit extract against indomethacininduced gastric ulceration in rats. Life Sci J. 2011;8(3):433-445.

13. Alami R, Macksad AS. Medicinal plants in Kuwait. Kuwait; 1974.

14. Ficarra R, Ficarra P, Tommasini S, Calabro ML, Ragusa S, Barbera $\mathrm{R}$, et al. Leaf extracts of some Cordia species: analgesic and anti-inflammatory activities as well as their chromatographic analysis. Farmaco (Societa Chimica Italiana: 1989). 1995;50(4):245-256.

15. Al-Awadi FM, Srikumar TS, Anim JT, Khan I. Antiinflammatory effects of Cordia myxa fruit on experimentally induced colitis in rats. Nutrition. 2001;17(5):391-396.

16. Ranjbar M, Varzi HN, Sabbagh A, Bolooki A, Sazmand A. Study on analgesic and anti-inflammatory properties of Cordia myxa fruit hydro-alcoholic extract. Pak J Biol Sci. 2013;16(24):2066-2069.

17. Abdul Hamza NN, Al-Tahan FJ. Potentiation of the analgesic effect of mefenamic acid (Ponstan) by Cordia myxa Linn fruit. InProceeding of the Ninth Veterinary Scientific Conference - Baghdad. 2009; Vol. 2, pp. 180182.

18. Olaniyan OT, Kunle-Alabi OT, Raji Y. Protective effects of methanol extract of Plukenetia conophora seeds and $4 \mathrm{H}$ Pyran-4-One 2, 3-Dihydro-3, 5-Dihydroxy-6-Methyl on the reproductive function of male Wistar rats treated with cadmium chloride. JBRA assisted reproduction. 2018;22(4):289-300.

19. Alkiyumi SS, Abdullah MA, Alrashdi AS, Salama SM, Abdelwahab SI, Hadi AH. Ipomoea aquatica extract shows protective action against thioacetamide-induced hepatotoxicity. Molecules. 2012;17(5):6146-6155.

20. Umarani V, Muvvala S, Ramesh A, Lakshmi BV, Sravanthi N. Rutin potentially attenuates fluoride-induced oxidative stress-mediated cardiotoxicity, blood toxicity and dyslipidemia in rats. Toxicology Mechanisms and Methods. 2015;25(2):143-149.

21. Al-Rejaie SS, Aleisa AM, Sayed-Ahmed MM, AL-Shabanah OA, Abuohashish HM, Ahmed MM, et al. Protective effect 
of rutin on the antioxidant genes expression in hypercholestrolemic male Westar rat. BMC Complementary and Alternative Medicine. 2013;13:136. Doi: 10.1186/1472-6882-13-136.

22. Khan RA, Khan MR, Sahreen S. CCl 4-induced hepatotoxicity: protective effect of rutin on p53, CYP2E1 and the antioxidative status in rat. BMC Complement Altern Med. 2012; Oct. 8;12:178. Doi: 10.1186/14726882-12-178

23. Hsu CL, Wu CH, Huang SL, Yen GC. Phenolic compounds rutin and o-coumaric acid ameliorate obesity induced by high-fat diet in rats. Journal of Agricultural and Food Chemistry. 2009;57(2):425-431.

24. de Jong A, Plat J, Lütjohann D, Mensink RP. Effects of long-term plant sterol or stanol ester consumption on lipid and lipoprotein metabolism in subjects on statin treatment. British Journal of Nutrition. 2008;100(5):937941.

25. Rideout TC, Marinangeli CP, Harding SV. Triglyceridelowering response to plant sterol and stanol consumption. Journal of AOAC International. 2015;98(3):707-715.

26. Rideout TC, Ramprasath V, Griffin JD, Browne RW, Harding SV, Jones PJ. Phytosterols protect against dietinduced hypertriglyceridemia in Syrian golden hamsters. Lipids Health Dis. 2014 Jan 6;13:5. Doi: 10.1186/1476511X-13-5.

27. Matsuyama T, Shoji K, Takase H, Kamimaki I, Tanaka Y, Otsuka A, et al. Effects of phytosterols in diacylglycerol as part of diet therapy on hyperlipidemia in children. Asia Pacific Journal of Clinical Nutrition. 2007;16(1):40-48.

28. Liu Q, Pan R, Ding L, Zhang F, Hu L, Ding B, et al. Rutin exhibits hepatoprotective effects in a mouse model of non-alcoholic fatty liver disease by reducing hepatic lipid levels and mitigating lipid-induced oxidative injuries. International Immunopharmacology. 2017;49:132-141.

29. Erdogan E, Ilgaz Y, Gurgor PN, Oztas Y, Topal T, Oztas E. Rutin ameliorates methotrexate induced hepatic injury in rats. Acta Cirurgica Brasileira. 2015;30(11):778-784.

30. Pan PH, Lin SY, Wang YY, Chen WY, Chuang YH, Wu CC, et al. Protective effects of rutin on liver injury induced by biliary obstruction in rats. Free Radical Biology and Medicine. 2014;73:106-116.

31. AlSharari SD, Al-Rejaie SS, Abuohashish HM, Ahmed MM, Hafez MM. Rutin attenuates Hepatotoxicity in highcholesterol-diet-fed rats. Oxidative Medicine and Cellular Longevity. 2016;2016:5436745. Doi: $10.1155 / 2016 / 5436745$.

32. Olayinka ET, Ola OS, Ore A, Adeyemo OA. Ameliorative Effect of Caffeic Acid on Capecitabine-Induced Hepatic and Renal Dysfunction: Involvement of the Antioxidant Defence System. Medicines (Basel). 2017; Oct. 25; 4(4). pii: E78. Doi: 10.3390/medicines4040078.

33. Li M, Wang XF, Shi JJ, Li YP, Yang N, Zhai S, et al. Caffeic acid phenethyl ester inhibits liver fibrosis in rats. World Journal of Gastroenterology. 2015; 21(13):3893-3903.

34. Yang N, Dang S, Shi J, Wu F, Li M, Zhang X, et al. Caffeic acid phenethyl ester attenuates liver fibrosis via inhibition of TGF- $\beta 1 /$ Smad3 pathway and induction of autophagy pathway. Biochemical and Biophysical Research Communications. 2017;486(1):22-28.

35. Pang C, Zheng Z, Shi L, Sheng Y, Wei H, Wang Z, et al. Caffeic acid prevents acetaminophen-induced liver injury by activating the Keap1-Nrf2 antioxidative defense system. Free Radical Biology and Medicine. 2016;91:236246. 